\title{
Proposal of National Collection of Dairy Organisms Strain 617 as the Neotype Strain of Streptococcus raffinolactis Orla- Jensen and Hansen
}

\author{
ELLEN I. GARVIE \\ National Institute for Research in Dairying, Shinfield, Reading RG2 9AT, England \\ National Collection of Dairy Organisms strain 617 is proposed as the neotype \\ strain of Streptococcus raffinolactis Orla-Jensen and Hansen. A description of \\ the organism is given.
}

Streptococcus raffinolactis was originally named and described by Orla-Jensen and Hansen (3). This streptococcus was found only in spontaneously soured milk, where it occurred as diplococci. It grew at $4^{\circ} \mathrm{C}$ and fermented sucrose, mannitol, raffinose, fructose, glucose, mannose, galactose, maltose, lactose, dextrin, and salicin. It did not ferment arabinose, rhamnose, sorbitol, inulin, or starch. Some strains formed slight acid from glycerol and xylose. Most strains took several days to curdle milk when incubated at $23^{\circ} \mathrm{C}$ and formed $L(+)$ lactic acid.

None of the strains on which Orla-Jensen and Hansen based their original description of $S$. raffinolactis appears to be extant. Thus it is necessary to propose a neotype strain. Garvie (2) identified strains isolated from spontaneously soured milk as members of $S$. raffino. lactis. Three of these strains are now kept in the National Collection of Dairy Organisms (NCDO) under the numbers 617,618 , and 619.

The properties of the strains examined by Garvie were published earlier $(1,2)$, and the properties of NCDO 617 (23.C.1) were also reported by Swartling (4), who reported that this strain formed acid from sorbitol, but Garvie (1) found that none of the strains she examined fermented sorbitol. NCDO 617 is a gram-positive coccobacillus occurring in pairs and short chains. This strain produces acid in litmus milk culture, and the litmus is reduced; however, the milk is clotted only after several days of incubation, if at all. It grows at 10 but not at $40^{\circ} \mathrm{C}$ and in $2 \%$ but not $4 \% \mathrm{NaCl}$; it does not grow at $\mathrm{pH} 9.2$ and does not survive heating at $60^{\circ} \mathrm{C}$ for $30 \mathrm{~min}$. Arginine is not hydrolyzed and gelatin is not liquefied. $\mathrm{CO}_{2}$ is not formed from glucose. Acetoin is not formed from lactose plus citric acid. Acid is formed from xylose, fructose, galactose, glucose, mannose, lactose, maltose, sucrose, trehalose, raffinose, dextrin, glycerol, esculin, and salicin but not from arabinose, inulin, starch, or mannitol. NCDO 617 belongs to serological group $\mathrm{N}$. The guanine-plus-cytosine content of its deoxyribonucleic acid is $41.5 \mathrm{~mol} \%$, and there is only $36 \%$ hybridization between the deoxyribonucleic acid of NCDO 617 and that of Streptococcus lactis NCDO 2031 and that of Streptococcus cremoris NCDO 924 (2). The only difference recorded between NCDO 617 and the strains described originally by Orla-Jensen and Hansen is in the fermentation of mannitol.

NCDO 617 is therefore here proposed as the neotype strain of $S$. raffinolactis Orla-Jensen and Hansen.

\section{LTERATURE CITED}

1. Garvie, E. I. 1953. Some group N streptococci isolated from raw milk. J. Dairy Res. 20:41-44.

2. Garvie, E. I. 1978. Streptococcus raffinolactis Orla-Jensen and Hansen. a group $\mathbf{N}$ streptococcus found in raw milk. Int J. Syst. Bacteriol. 28:190-193.

3. Orla-Jensen, A. D., and P. A. Hansen. 1932. The bacteriological flora of spontaneously soured milk and of commercial starters for butter making. Zentralbl. Bakteriol. Parasitenkd. Infektionskr Hyg. Abt. 2 86:629.

4. Swartling, P. 1951. Biochemical and serological properties of some citric acid fermenting streptococci from milk and dairy products. J. Dairy Res. 18:256-267. 